\title{
Control of IGFBP-2 expression by steroids and peptide hormones in vertebrates
}

\section{Andreas Hoeflich ${ }^{1}$, Elisa Wirthgen ${ }^{2}$, Robert David ${ }^{3}$, Carl Friedrich Classen $^{4}$, Marion Spitschak $^{1}$ and Julia Brenmoehl'}

1 Institute of Genome Biology, Leibniz Institute for Farm Animal Biology (FBN), Dummerstorf, Germany

2 Ligandis GbR, Gülzow, Germany

${ }^{3}$ Reference and Translation Center for Cardiac Stem Cell Therapy, Rostock, Germany

${ }^{4}$ Pediatric Oncology, University Children's Hospital, Rostock, Germany

\section{Edited by:}

Haim Werner, Tel Aviv University, Israel

\section{Reviewed by:}

Briony Forbes, The University of Adelaide, Australia

Haim Werner, Tel Aviv University, Israel

*Correspondence:

Andreas Hoeflich, Institute of Genome Biology, Leibniz Institute for Farm Animal Biology (FBN),

Wilhelm-Stahl-Allee 2, Dummerstorf 18196, Germany

e-mail: hoeflich@fbn-dummerstorf.de
IGFBP-2 (1) has been described as a brain tumor oncogene (2) and is widely expressed in cancers from different origins (3-8). IGFBP-2 alone cannot cause malignant transformation, yet progression of brain tumors to higher grade (9) and also has been provided as a protective element in earlier stages of multistage colon carcinogenesis (10). Therefore, it is crucial to understand the factors that determine expression patterns of IGFBP-2 under normal and malignant conditions. The present review provides a comprehensive update of known factors that have an impact on expression of IGFBP-2.

Keywords: IGFBP-2, steroids, estradiol, peptide hormones, vertebrates

\section{INTRODUCTION}

Shortly after the identification of IGFBP-2 (1), it was realized that its expression both in liver and ovary is induced by E2 (Table 1) in hypophysectomized rats (11). Notably, hypophysectomy increased IGFBP-2 mRNA levels in the liver but decreased IGFBP-2 gene expression in the ovary. In the following 10 years of IGFBP-2 research, particular interest was taken in the somatotropic control of IGFBP-2 (8). However, it also was realized soon, that the gonadotropic axis may play a particular role in the control of IGFBP-2 expression (12). Just recently, Foulstone and coworkers have identified a feedback loop between IGFBP-2 and the ERa (estrogen receptor-alpha), whereby both factors can mutually induce gene expression of each other (13). This particular finding further underlined the current need for a detailed meta-analysis that is dedicated to the question which factors presently are known to control expression of IGFBP-2?

\section{IGFBP-2 PROMOTER REGION}

First of all, tissue- and stage-specific expression patterns of IGFBP2 are defined by endogenous stimulatory or repressor promoter elements within the IGFBP-2 gene. The promoter region of the gene encoding IGFBP-2 contains putative Sp1 binding sites (1, 85-87), potential response elements for E2 and P4 receptors, and overlapping sequences for albumin D-box binding (88). Kwak et al.

Abbreviations: AR, androgen receptor; AKT, protein kinase B; DHEA, dehydroepiandrosterone; E2, 17 $\beta$-estradiol; ER, estrogen receptor; $\mathrm{FSH}$, follicle stimulating hormone; GH, growth hormone; GHR, GH receptor; IGF, insulin-like growth factor; IGFBP, IGF binding protein; IGF1R, IGF-I receptor; LH, luteinizing hormone; mTOR, mammalian target of rapamycin; PTEN, phosphatase and tensin homolog; $\mathrm{P} 4$, progesterone; $\mathrm{T}$, testosterone. have studied the structural basis for the stage-specific expression of IGFBP-2 in the porcine endometrium during pregnancy and identified two novel cis-elements in the promoter region of the IGFBP-2 gene (89). In this study, an endometrial 34-kDa nuclear binding protein was characterized with potential repressor functions for IGFBP-2 gene expression. These might confer site- and stage-specific expression of IGFBP-2 during pregnancy. Furthermore, a distal enhancer-like region, identified earlier in hepatic HepG2 cells (90) is active in the porcine endometrium (89). Four putative binding sites for NF-kB have been identified in lung alveolar epithelial cells isolated from rats that were exposed to oxygen (73). This finding by Cazals and coworkers may provide the functional basis for the effects of hyperoxia or hypoxia on IGFBP-2 expression described so far $(74-76,81)$. In small cell lung cancer cell lines, a proximal E-box was identified that binds NeuroD and thereby induces IGFBP-2 expression (77). In 11 out of 12 primary small cell lung cancer tissues assessed, the IGFBP-2 promoter was present in an unmethylated form, which confers higher gene expression in comparison with other histological subtypes (77). Since NeuroD is expressed also in other neuroectodermal cells, NeuroD-dependent induction of IGFBP-2 expression was discussed also for retinoblastomas, medulloblastomas, or neuroblastomas (77). However, also prostate carcinoma cells are known to express NeuroD (91) and, as discussed further down, also IGFBP2. In human breast cancer cells (MCF-7), Mireuta and coworkers could demonstrate that the proximal promoter region of IGFBP-2 is activated by an IGF-I/PI3K/AKT/mTOR-dependent manner via an increase of nuclear Sp1 (44). The authors discussed the potential use of Sp1 inhibitors particularly in cancers that highly express IGFBP-2. Two potential androgen binding sites have been identified via bioinformatic analysis of the region upstream from the 
Table 1 | Cell- and tissue-specific control of IGFBP-2 expression in vertebrates.

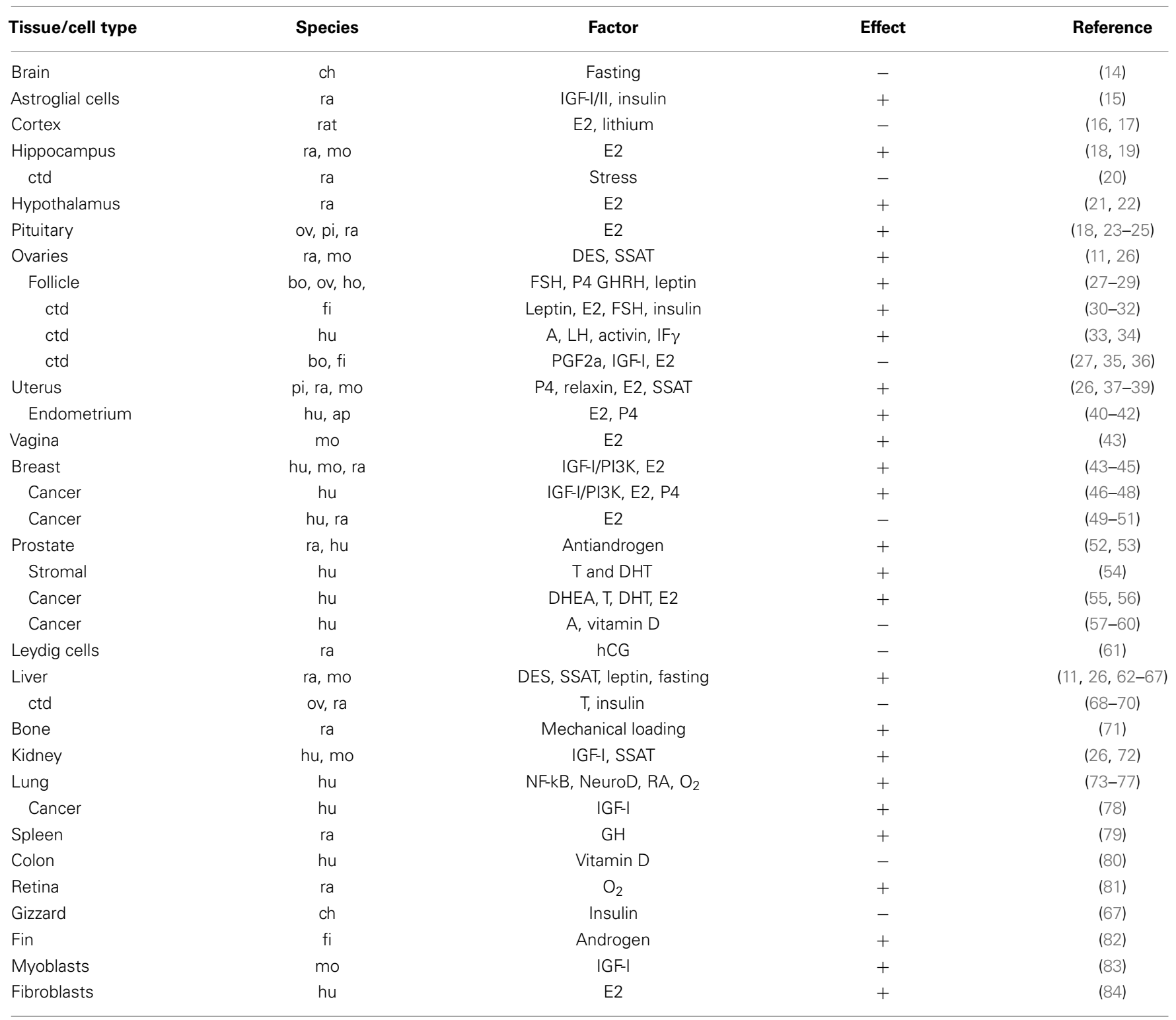

hu, human; ap, ape; pi, pig; ov, ovine; bo, bovine; ra, rat; mo, mouse; co, cony; ch, chicken; fi, fish; E2, estradiol; P4, progesterone; DES, diethylstilbestrol; SSAT, spermidine/spermine N1-acetyltransferase; FSH, follicle stimulating hormone; GHRH, GH releasing hormone; $P G F$, prostaglandin F; DH/T, dihydro/testosterone; DHEA, dehydroepiandrosterone; RA, retinoic acid; LH, luteinizing hormone; IF, interferon gamma; hCG, human chorionic gonadotropin; ctd, continued.

IGFBP-2 transcription initiation site that may explain the effects of androgen treatment on IGFBP-2 gene expression as demonstrated in prostate cancer cells $(57,58)$.

\section{CONTROL OF IGFBP-2 EXPRESSION IN THE BRAIN}

More than 20 years ago, Pons and Torres-Aleman found that E2 significantly increases protein levels of IGFBP-2 in cultures of hypothalamic neurons isolated from rats (21). In vivo, application of E2 to ovariectomized rats also increased IGFBP-2 immunoreactivity in tanycytes and other ependymal cells of the hypothalamus (22). On the other hand, P4 led to reduced IGFBP-2 protein levels in the apical membrane of tanycytes in the same model. In both reports, functional interaction of steroids and the IGF-system was discussed. Also in the anterior pituitary glands from sheep (23), pigs (24), or rats (25) E2 increased IGFBP-2 levels. A positive effect of E2 on IGFBP-2 mRNA expression was present in MtT/S and GH3 cell lines established from rat pituitary adenomas (18). Notably, E2 seems to be permissive for steady state IGFBP-2 levels in the anterior pituitary since reduction of estrogens by use of anastrozole in boars decreased expression of IGFBP-2 (92). In contrast, DHEA increased IGF-I expression in the hypothalamus of rats but did not affect expression of IGFBP-2 (93). Estradiol further increased expression of IGFBP-2 mRNA in the hippocampus of ovariectomized rats (18) or in the hippocampus from normal mice $1 \mathrm{~h}$ after injection (19). Interestingly, also mice subjected to neonatal isolation had reduced hippocampal IGFBP-2 mRNA 
expression in adulthood when exposed to restraint stress (20). During hormone replacement therapy, E2 downregulated IGFBP2 mRNA in the frontal cortex of ovariectomized rats (16). IGFBP-2 mRNA expression was robustly down regulated also by lithium in primary cell cultures from rat cortices (17).

The important role of IGFBP-2 in malignant brain tumors, particularly glioblastoma, has already been mentioned. Reactivation of IGFBP-2 expression in glioblastoma multiforme was discussed in a context of defect astrocyte differentiation and PI3K/AKT activation (94-96). Conversely, a stable knockdown of IGFBP-2 resulted in decreased invasiveness, decreased saturation density of the cells in vitro, and decreased tumorigenicity in nude mice (97).

A strong inverse relationship between elevated IGFBP-2 levels and low $\mathrm{p} 16^{\mathrm{INK} 4 \mathrm{a}}$ indicates a negative regulatory function of p16 ${ }^{\mathrm{INK} 4 \mathrm{a}}$ for IGFBP-2 (98) similar to the negative correlation of IGFBP-2 mRNA and PTEN expression levels found both in glioblastomas and prostate cancers, implicating IGFBP-2 as a biomarker for PTEN status (95). This may be in concordance with an observation of E2-induced apoptosis of glioblastoma cells (99). The inverse relationship between IGFBP-2 and PTEN expression is not restricted to malignant cells and has been described also during osteoclast differentiation (100).

\section{CONTROL OF IGFBP-2 EXPRESSION IN FEMALE REPRODUCTIVE TISSUES}

Hormone replacement therapy over 15 months to postmenopausal women revealed a negative effect of E2 on serum IGFBP-2 concentrations (101). Also in human adolescents with constitutional tall stature, E2 reduced serum IGFBP-2 concentrations 3 and 6 months after starting the therapy (102). In contrast, in aged women and men supplementation of sex steroids over a period of 6 months revealed no effect of a hormone replacement therapy or testosterone on IGFBP-2 serum levels (103). In human granulosa cells, $\mathrm{LH}$, activin, and interferon gamma increased expression of IGFBP2 (33) and insulin and androstendione increased secretion of IGFBP-2 into cell conditioned media (34). After the preovulatory surge of $\mathrm{LH}$, when steroid levels are low, an inverse relationship between follicular IGFBP-2 concentrations and steroid (E2, androstendione and P4) concentrations has been described in sows already in 1992 (104). FSH increased whereas prostaglandin F2a decreased IGFBP-2 concentrations in bovine ovarian follicular fluid and low levels of IGFBP-2 in E2-active follicles suggested a role of IGFBP-2 for aromatase activity (27). By contrast, P4 treatment in cattle increased protein levels of IGFBP-2 in follicular fluids (28). In equine granulosa cells, both E2 and FSH induced expression of IGFBP-2 in vitro (30). Furthermore, in follicles, also the GH/IGF axis is involved in the control of IGFBP-2 expression. Application of growth hormone releasing hormone in cattle increased IGFBP-2 in the circulation and in the fluid from subordinated but not from dominant follicles (29). As described earlier for E2, also human recombinant IGF-I decreased IGFBP-2 mRNA expression and protein levels in granulosa cells and the oocytes from cultures bovine antral follicles in a stage- and dose-specific manner (35). In addition, granulosa cells from bovine follicles but not the oocyte have been shown to produce an IGFBP-2 protease (105). Thus, also IGFBP-2 protein stability is under active control in bovine follicles. Finally, leptin infusion for 3 days in cycling ewes increased follicular IGFBP-2 mRNA expression although this effect may be related to other hormones since at the same time insulin and FSH serum concentrations were increased while those of E2 were reduced (31).

IGFBP-2 secretion is stimulated by E2 and P4 in human endometrial stromal cells and in endometrial explants from baboons $(40,41)$. Short-term E2/P4 treatment of ovariectomized monkeys over 2 weeks increased IGFBP- 2 mRNA in the myometrium in response to $\mathrm{E} 2$ and to a higher degree after treatment both with E2 and P4 (42). High amounts of IGFBP-2 mRNA are found in the porcine uterus (106), which might be related to the specific IGFBP-2 promoter configuration as summarized above (88). Progesterone increased gene expression of IGFBP-2 in pig uteri while E2 slightly reduced mRNA levels of IGFBP2 (37). Notably, the trophic effects of relaxin administration on uterine weight in pigs were accompanied by robust increase of IGFBP-2 as found as a band doublet in uterine flushes (38). High IGFBP-2 levels in earlier but not in later phases of the estrus in pigs are potentially due to kallikrein/matrix metalloproteases (107). In fact, kallikrein, matrix metalloprotease 3, or plasminogen activator were sufficient to rapidly degrade IGFBP2 in uterine flushes or breast milk from pigs (107) or humans (108), respectively. Six hours after E2 injection in mice, IGFBP2 mRNA expression was increased in the mammary gland but even more in the vagina (43). Similarly, E2 treatment significantly increased IGFBP-2 mRNA levels also in uteri of ovariectomized rats (39). A robust increase of IGFBP-2 gene expression was further found in uteri from mice characterized by transgenic spermidine/spermine N1-acetyltransferase (SSAT) expression (26). Steroid control of IGFBP-2 is also observed in non-mammalian species as gonadotropin, E2, and $\mathrm{P} 4$ were able to increase expression of IGFBP-2 mRNA in de-yolked follicles from the rainbow trout (32) whereas E2 decreased IGFBP-2 mRNA expression in the orange-spotted grouper (36).

\section{CONTROL OF IGFBP-2 EXPRESSION IN BREAST CANCER CELLS}

In human breast cancer cells (MCF-7), IGF-I potently induced expression of IGFBP-2 (46) and E2 enhanced the effect of IGFI with its basal activity being on a lower level if compared to IGF-I (47). Martin and Baxter further demonstrated that both the effects of IGF-I and E2 were mediated by the PI3/AKT pathway since inhibitors of IGF1R, PI3K, and mTOR blocked the basal effects of IGF-I and E2 (47). Also in mammary glands from rats, E2 increased mRNA expression of IGFBP-2 mRNA (45), while in pseudo-pregnant pigs E2 injection did not affect mammary IGFBP-2 mRNA expression (109). In invasive (MCF-7/6) or in breast cancer cell lines adapted to low serum concentrations (MCF-7/S0.5) $(49,50)$ and in Fischer rat mammary adenocarcinoma cells (51), E2s suppressed intracellular and/or secreted levels of IGFBP-2. Nevertheless, secretion of IGFBP-2 was lower in ER-negative breast cancer cells compared to ER-positive cells indicating a positive or at least a permissive effect of ER on IGFBP-2 expression in mammary cells (110). Therefore, similar to cells from the brain a synergistic effect of E2 and P4 on IGFBP-2 secretion was found in breast cancer explants (48). Since this was true only for hormone-sensitive but not for hormone-insensitive samples, 
it also supports at least a permissive role of ER for the functional relationships between E2- and P4-signaling on the one hand and IGFBP-2 expression on the other. Furthermore, IGFBP-2 is highly expressed by antiestrogen-resistant breast cancer cell lines (111) and in antiestrogen-resistant RU58R-1 cells, IGFBP-2 expression was suppressed by E2 but massively stimulated by pure antiestrogen (50). Therefore, an indirect effect of E2 and the interaction of estrogens and IGFs has been suggested (49). In fact, a dedicated review discusses the crosstalk between IGFs and E2 (112) with E2 being introduced as an enhancer of IGF-signaling pathways in breast cancer. This kind of view was further elaborated and thus supported by the work of Chan et al., who described significant activation of IGF1R, IRS-1 and -2, AKT, and PI3K in response to E2 in the rat mammary gland (45).

\section{CONTROL OF IGFBP-2 IN PROSTATE CELLS}

In primary human prostate stromal cells and in human prostate cancer cells (LNCaP), androgens and in part also E2 significantly induced IGFBP-2 mRNA expression (54-56). Flutamide, an androgen receptor antagonist, blocked androgen-dependent induction of IGFBP-2 expression (54). Also antisense oligonucleotides or antiandrogen treatment reduced gene expression of IGFBP-2 in LNCaP cells (113). It was speculated, that the effects of DHT and T are mediated by the AR. Looking at the level of protein, it was demonstrated that androgen treatment rapidly decreased IGFBP-2 levels in LNCaP cells (59). Notably, negative androgen regulation of IGFBP-2 secretion involved extracellular proteolytic cleavage (59). A reduction of IGFBP-2 proteolysis in androgen-insensitive prostate carcinoma cells increased the metastatic potential in that study. Androgen-dependent regulation of IGFBP-2 mRNA expression might be established by means of the IGFBP-2 promoter specifically, as stated earlier, but also by an effect on global protein translation: unexpectedly, androgen treatment of prostate carcinoma cells for an extended period of time $(48 \mathrm{~h})$ downregulated the polysomal fraction of mRNA and thus global protein synthesis (57). Further supporting negative effects of androgens, castration induced gene expression of IGFBP-2 in the rat ventral prostate (114). Also antiandrogenic treatment increased tissue levels of IGFBP-2 in human patients (52) or in rats (53). Therefore, reports are available that demonstrate or suggest positive or negative (58) effects of androgens both on mRNA and protein levels of IGFBP-2 depending on the physiological condition in prostate cells.

\section{CONTROL OF IGFBP-2 BY GH AND IGFs}

Zapf et al. performed the initial study on hormonal control of IGFBP-2 by GH and IGF-I (115). In this study, GH suppressed expression of IGFBP-2 while IGF-I increased this particular IGFBP as demonstrated by Western ligand blotting. Notably, GH suppressed the effect of IGF-I on IGFBP-2 concentration. After development of a specific radioimmunoassay by Blum and coworkers (116), higher levels of IGFBP-2 have been quantified during GH deficiency and IGF-I administration whereas reduced IGFBP-2 levels were present in acromegalic patients. An inverse relationship between IGFBP-3 and IGFBP-2 was diagnosed (116), indicating that GH is a suppressor of IGFBP-2 expression. This finding was repeatedly confirmed by others and may represent the basis for altered IGFBP-2 levels during fasting, in aging, or impaired liver function as suggested, e.g., by Bannink and coworkers (117). Exogenous GH downregulates IGFBP-2 in humans (117-119), whereas impaired GH receptor signaling in mice (120) elevated IGFBP-2 serum levels. Although not confirmed as a rule $(121,122)$, the strength of the inverse relationship between GH and IGFBP-2 and its bidirectional nature suggested the use of IGFBP-2 levels as a biomarker to monitor GH-doping (123) or IGF/IGFBP-3 misuse in male and female athletes (124). Interestingly, testosterone blocked the negative effects of growth hormone on IGFBP-2 levels in men (103) and in GHR-deficient mice testosterone increased serum levels of IGFBP-2 (125). Conditional effects of GH have been described with more suppressive effects on IGFBP-2 levels in lean versus obese sheep (126). To date, exclusively in the spleen from juvenile rats exogenous $\mathrm{GH}$ stimulated gene expression of IGFBP-2 in that particular tissue (79).

IGF-I increased IGFBP-2 in human subjects (121, 127), in human embryonic kidney fibroblasts (72), in human lung adenocarcinoma cells (78), in transgenic rabbits (128), in rat astroglial cells (15), or in mouse C2C12 myoblasts (83). Administration of pegylated IGF-I in mice increased serum levels of IGFBP-2 up to $30 \mu \mathrm{g} / \mathrm{ml}$, which corresponds to an increase of 1-2 magnitudes (129). Positive correlations of serum levels between IGF-II and IGFBP-2 have been frequently observed, e.g., in human subjects (116) or in IGF-II transgenic mouse models $(130,131)$. Thus, also IGF-II has been considered as a major regulator of IGFBP-2 expression. In the medulla oblongata of IGF-II transgenic mice, protein levels of IGFBP-2 were 10-fold upregulated if compared to non-transgenic mice (132). IGF-II also increased secretion of IGFBP-2 by primary rat astroglial cells (15). An interaction of IGF-I and estrogens has been discussed in women with anorexia nervosa (133). In that setting, E2 reduced IGF-dependent increase of IGFBP-2, which was discussed in a context with higher levels of free IGF-I in the presence of estrogens.

\section{CONTROL OF IGFBP-2 EXPRESSION BY DIET AND INSULIN}

IGFBP-2 has been provided as an antidiabetic and antiobesity protein by the pioneer work of Wheatcroft and coworkers (134). This finding was confirmed and leptin was shown also to stimulate hepatic expression of IGFBP-2 (62). Accordingly, an important role of IGFBP-2 for metabolic homeostasis has been discussed (135). On the other hand, in humans serum concentrations of IGFBP-2 can be increased by protein or carbohydrate intake (136138). In addition, also single supplementations, e.g., lycopene in humans (139), or vitamin D analogs in cancer cell lines (60, 80) can induce or repress IGFBP-2 concentrations. Serum levels of IGFBP-2 were positively associated with insulin infusion in humans (140) and negatively correlated in dairy cows $(141,142)$. With exceptions (121), fasting increased serum levels of IGFBP-2 from humans to chicken and re-feeding normalized high fasting IGFBP-2 serum levels (130, 143-146). So far, in catfish, fasting did not affect IGFBP-2 expression (147). Altered serum levels may be due to hepatic expression of IGFBP-2 mRNA, which is increased in fasted or diabetic rats (63-66). Also in chicken, fasting increased IGFBP-2 expression in the liver and gizzard, and insulin administration decreased IGFBP-2 expression in both tissues (67). By contrast, in the brain, fasting efficiently reduced expression of 
IGFBP-2 mRNA as shown by Kita and coworkers in chicken (14). Insulin suppression of IGFBP-2 expression was also observed in hepatocytes isolated from rats $(68,69)$. However, dietary control of IGFBP-2 expression seems to occur also in non-hepatic cells, since insulin significantly increased mRNA expression of IGFBP2 in primary rat astroglial cells (15). Nutritional regulation of IGFBP-2 also expands into the ovaries from sheep, where dietary factors (infusion of glucose and glucosamine or lupine supplementation) increased its expression in follicular granulosa cells. Thereby, higher IGFBP-2 levels correlated with the number of atretic follicles (148).

\section{SUMMARY AND CONCLUSION}

Expression of IGFBP-2 is depending on tropic signals from the IGF/PI3K pathway, dietary factors, and oxygen. However, in a wide variety of tissues, steroids have been identified as effectors of IGFBP-2 expression. Steroids may impact on the level of IGFBP-2 mRNA and protein expression or stability. In addition to reproductive organs particularly within the brain steroids have major effects on the expression of IGFBP-2. Above all other steroids, E2 appears to have a particular function for the control of IGFBP2 levels. Furthermore, in different tissues E2 seems to modulate IGF-signaling pathways. With respect to IGFBP-2 levels, interactions of GH/IGF-signals and steroid signals seem to exist on the level of cytosolic signal transduction but also on the level of RNA transcription within the cell nucleus. Those interactions might provide novel molecular targets in the prevention or therapy of malignant or metabolic diseases (2-7). Looking back at 25 years of IGFBP-2 research, the dominant role of E2 for regulation of IGFBP-2 activity is intriguing. To date, the understanding of functional interrelations between IGFBP-2 and steroids is likely just in its beginnings.

\section{ACKNOWLEDGMENTS}

This work was supported by a grant from the Deutsche Forschungsgemeinschaft (DFG HO2003/6-1).

\section{REFERENCES}

1. Binkert C, Landwehr J, Mary JL, Schwander J, Heinrich G. Cloning, sequence analysis and expression of a cDNA encoding a novel insulin-like growth factor binding protein (IGFBP-2). EMBO J (1989) 8:2497-502.

2. Zhang W, Fuller G. IGFBP2 as a brain tumor oncogene. Cancer Biol Ther (2007) 6:995-6.

3. Chi F, Wu R, Zeng YC, Xing R, Liu Y. Circulation insulin-like growth factor peptides and colorectal cancer risk: an updated systematic review and metaanalysis. Mol Biol Rep (2013) 40:3583-90. doi:10.1007/s11033-012-2432-z

4. Rowlands MA, Gunnell D, Harris R, Vatten LJ, Holly JM, Martin RM. Circulating insulin-like growth factor peptides and prostate cancer risk: a systematic review and meta-analysis. Int J Cancer (2009) 124:2416-29. doi:10.1002/ijc. 24202

5. Fukushima T, Kataoka H. Roles of insulin-like growth factor binding protein-2 (IGFBP-2) in glioblastoma. Anticancer Res (2007) 27:3685-92.

6. Fottner C, Hoeflich A, Wolf E, Weber MM. Role of the insulin-like growth factor system in adrenocortical growth control and carcinogenesis. Horm Metab Res (2004) 36:397-405. doi:10.1055/s-2004-814563

7. Firth SM, Baxter RC. Cellular actions of the insulin-like growth factor binding proteins. Endocr Rev (2002) 23:824-54. doi:10.1210/er.2001-0033

8. Hoeflich A, Reisinger R, Lahm H, Kiess W, Blum WF, Kolb HJ, et al. Insulinlike growth factor-binding protein 2 in tumorigenesis: protector or promoter? Cancer Res (2001) 61:8601-10.
9. Dunlap SM, Celestino J, Wang H, Jiang R, Holland EC, Fuller GN, et al. Insulinlike growth factor binding protein 2 promotes glioma development and progression. Proc Natl Acad Sci U S A (2007) 104:11736-41. doi:10.1073/pnas. 0703145104

10. Diehl D, Hessel E, Oesterle D, Renner-Müller I, Elmlinger M, Langhammer M, et al. IGFBP-2 overexpression reduces the appearance of dysplastic aberrant crypt foci and inhibits growth of adenomas in chemically induced colorectal carcinogenesis. Int J Cancer (2009) 124:2220-5. doi:10.1002/ijc.24193

11. Ricciarelli E, Hernandez ER, Hurwitz A, Kokia E, Rosenfeld RG, Schwander J, et al. The ovarian expression of the antigonadotropic insulin-like growth factor binding protein-2 is theca-interstitial cell-selective: evidence for hormonal regulation. Endocrinology (1991) 129:2266-8. doi:10.1210/endo-129-4-2266

12. Giudice LC, Milkowski DA, Lamson G, Rosenfeld RG, Irwin JC. Insulin-like growth factor binding proteins in human endometrium: steroid-dependent messenger ribonucleic acid expression and protein synthesis. J Clin Endocrinol Metab (1991) 72:779-87. doi:10.1210/jcem-72-4-779

13. Foulstone EJ, Zeng L, Perks CM, Holly JM. Insulin-like growth factor binding protein 2 (IGFBP-2) promotes growth and survival of breast epithelial cells: novel regulation of the estrogen receptor. Endocrinology (2013) 154:1780-93. doi:10.1210/en.2012-1970

14. Kita K, Nagao K, Taneda N, Inagaki Y, Hirano K, Shibata T, et al. Insulinlike growth factor binding protein-2 gene expression can be regulated by diet manipulation in several tissues of young chickens. J Nutr (2002) 132:145-51.

15. Bradshaw SL, Han VK. Hormonal regulation of astroglial insulin-like growth factor (IGF)-binding protein gene expression by IGFs and insulin. Endocrinology (1993) 133:1767-77. doi:10.1210/endo.133.4.7691580

16. Sárvári M, Kalló I, Hrabovszky E, Solymosi N, Tóth K, Likó I, et al. Estradiol replacement alters expression of genes related to neurotransmission and immune surveillance in the frontal cortex of middle-aged, ovariectomized rats. Endocrinology (2010) 151:3847-62. doi:10.1210/en.2010-0375

17. Bezchlibnyk YB, Wang JF, Shao L, Young LT. Insulin-like growth factor binding protein-2 expression is decreased by lithium. Neuroreport (2006) 17:897-901. doi:10.1097/01.wnr.0000220143.37036.32

18. Takeo C, Ikeda K, Horie-Inoue K, Inoue S. Identification of Igf2, Igfbp2 and Enpp2 as estrogen-responsive genes in rat hippocampus. Endocr J (2009) 56:113-20. doi:10.1507/endocrj.K08E-220

19. Pechenino AS, Frick KM. The effects of acute 17beta-estradiol treatment on gene expression in the young female mouse hippocampus. Neurobiol Learn Mem (2009) 91:315-22. doi:10.1016/j.nlm.2008.09.017

20. Erabi K, Morinobu S, Kawano K, Tsuji S, Yamawaki S. Neonatal isolation changes the expression of IGF-IR and IGFBP-2 in the hippocampus in response to adulthood restraint stress. Int J Neuropsychopharmacol (2007) 10:369-81. doi:10.1017/S1461145706006675

21. Pons S, Torres-Aleman I. Estradiol modulates insulin-like growth factor I receptors and binding proteins in neurons from the hypothalamus. JNeuroendocrinol (1993) 5:267-71. doi:10.1111/j.1365-2826.1993.tb00482.x

22. Cardona-Gomez GP, Chowen JA, Garcia-Segura LM. Estradiol and progesterone regulate the expression of insulin-like growth factor-I receptor and insulin-like growth factor binding protein-2 in the hypothalamus of adult female rats. J Neurobiol (2000) 43:269-81. doi:10.1002/(SICI)10974695(20000605)43:3<269::AID-NEU5>3.0.CO;2-D

23. Clapper JA, Snyder JL, Roberts AJ, Hamernik DL, Moss GE. Estradiol increases relative amounts of insulin-like growth factor binding protein (IGFBP)-3 in serum and expression of IGFBP-2 in anterior pituitaries of ewes. Biol Reprod (1998) 59:124-30. doi:10.1095/biolreprod59.1.124

24. Rempel LA, Clapper JA. Administration of estradiol-17beta increases anterior pituitary IGF-I and relative amounts of serum and anterior pituitary IGFbinding proteins in barrows. J Anim Sci (2002) 80:214-24.

25. Michels KM, Lee WH, Seltzer A, Saavedra JM, Bondy CA. Up-regulation of pituitary [125I] insulin-like growth factor-I (IGF-I) binding and IGF binding protein-2 and IGF-I gene expression by estrogen. Endocrinology (1993) 132:23-9. doi:10.1210/en.132.1.23

26. Min SH, Simmen RC, Alhonen L, Halmekyto M, Porter CW, Janne J, et al. Altered levels of growth-related and novel gene transcripts in reproductive and other tissues of female mice overexpressing spermidine/spermine N1acetyltransferase (SSAT). J Biol Chem (2002) 277:3647-57. doi:10.1074/jbc. M100751200 
27. Echternkamp SE, Howard HJ, Roberts AJ, Grizzle J, Wise T. Relationships among concentrations of steroids, insulin-like growth factor-I, and insulinlike growth factor binding proteins in ovarian follicular fluid of beef cattle. Biol Reprod (1994) 51:971-81. doi:10.1095/biolreprod51.5.971

28. Ginther OJ, Bergfelt DR, Beg MA, Kot K. Effect of LH on circulating oestradiol and follicular fluid factor concentrations during follicle deviation in cattle. Reproduction (2001) 122:103-10. doi:10.1530/rep.0.1220103

29. Stanko RL, Cohick WS, Shaw DW, Harvey RW, Clemmons DR, Whitacre $\mathrm{MD}$, et al. Effect of somatotropin and/or equine chorionic gonadotropin on serum and follicular insulin-like growth factor I and insulin-like growth factor binding proteins in cattle. Biol Reprod (1994) 50:290-300. doi:10.1095/ biolreprod50.2.290

30. Davidson TR, Chamberlain CS, Bridges TS, Spicer LJ. Effect of follicle size on in vitro production of steroids and insulin-like growth factor (IGF)-I, IGF-II, and the IGF-binding proteins by equine ovarian granulosa cells. Biol Reprod (2002) 66:1640-8. doi:10.1095/biolreprod66.6.1640

31. Muñoz-Gutiérrez M, Findlay PA, Adam CL, Wax G, Campbell BK, Kendall NR, et al. The ovarian expression of mRNAs for aromatase, IGF-I receptor, IGF-binding protein-2, -4 and -5 , leptin and leptin receptor in cycling ewes after three days of leptin infusion. Reproduction (2005) 130:869-81. doi:10.1530/rep.1.00557

32. Kamangar BB, Gabillard JC, Bobe J. Insulin-like growth factor-binding protein (IGFBP)-1, -2, -3, -4, -5, and -6 and IGFBP-related protein 1 during rainbow trout postvitellogenesis and oocyte maturation: molecular characterization, expression profiles, and hormonal regulation. Endocrinology (2006) 147:2399-410. doi:10.1210/en.2005-1570

33. Cataldo NA, Fujimoto VY, Jaffe RB. Interferon-gamma and activin A promote insulin-like growth factor-binding protein- 2 and -4 accumulation by human luteinizing granulosa cells, and interferon-gamma promotes their apoptosis. J Clin Endocrinol Metab (1998) 83:179-86. doi:10.1210/jcem.83.1.4481

34. Greisen S, Flyvbjerg A, Ledet T, Ovesen P. Regulation of insulin-like growth factor binding protein secretion by human granulosa luteal cells in a polycystic ovary-like environment. Fertil Steril (2002) 78:162-8. doi:10.1016/S00150282(02)03147-3

35. Walters KA, Binnie JP, Campbell BK, Armstrong DG, Telfer EE. The effects of IGF-I on bovine follicle development and IGFBP-2 expression are dose and stage dependent. Reproduction (2006) 131:515-23. doi:10.1530/rep.1.00682

36. Chen W, Wang Y, Li W, Lin H. Insulin-like growth factor binding protein-2 (IGFBP-2) in orange-spotted grouper, Epinephelus coioides: molecular characterization, expression profiles and regulation by 17beta-estradiol in ovary. Comp Biochem Physiol B Biochem Mol Biol (2010) 157:336-42. doi:10.1016/j. cbpb.2010.08.001

37. Simmen RC, Simmen FA, Hofig A, Farmer SJ, Bazer FW. Hormonal regulation of insulin-like growth factor gene expression in pig uterus. Endocrinology (1990) 127:2166-74. doi:10.1210/endo-127-5-2166

38. Ohleth KM, Lenhart JA, Ryan PL, Radecki SV, Bagnell CA. Relaxin increases insulin-like growth factors (IGFs) and IGF-binding proteins of the pig uterus in vivo. Endocrinology (1997) 138:3652-8. doi:10.1210/en.138.9.3652

39. Wu X, Pang ST, Sahlin L, Blanck A, Norstedt G, Flores-Morales A. Gene expression profiling of the effects of castration and estrogen treatment in the rat uterus. Biol Reprod (2003) 69:1308-17. doi:10.1095/biolreprod.103.015420

40. Giudice LC, Milkowski DA, Fielder PJ, Irwin JC. Characterization of the steroid-dependence of insulin-like growth factor-binding protein-2 synthesis and mRNA expression in cultured human endometrial stromal cells. Hum Reprod (1991) 6:632-40.

41. Fleming SD, Fazleabas AT, Bell SC. Differential regulation of insulin-like growth factor binding protein-1 and -2 by insulin in the baboon (Papio anubis) endometrium. Reprod Biol Endocrinol (2008) 6:6. doi:10.1186/1477-7827-6-6

42. Adesanya OO, Zhou J, Bondy CA. Cellular localization and sex steroid regulation of insulin-like growth factor binding protein messenger ribonucleic acids in the primate myometrium. J Clin Endocrinol Metab (1996) 81:2495-501. doi:10.1210/jc.81.7.2495

43. Suzuki A, Urushitani H, Watanabe H, Sato T, Iguchi T, Kobayashi T, et al. Comparison of estrogen responsive genes in the mouse uterus, vagina and mammary gland. J Vet Med Sci (2007) 69:725-31. doi:10.1292/jvms.69.725

44. Mireuta M, Darnel A, Pollak M. IGFBP-2 expression in MCF-7 cells is regulated by the PI3K/AKT/mTOR pathway through Spl-induced increase in transcription. Growth Factors (2010) 28:243-55. doi:10.3109/08977191003745472
45. Chan TW, Pollak M, Huynh H. Inhibition of insulin-like growth factor signaling pathways in mammary gland by pure antiestrogen ICI 182,780. Clin Cancer Res (2001) 7:2545-54.

46. Sheikh MS, Shao ZM, Hussain A, Clemmons DR, Chen JC, Roberts CT $\mathrm{Jr}$, et al. Regulation of insulin-like growth factor-binding-protein-1, 2, 3, 4, 5, and 6: synthesis, secretion, and gene expression in estrogen receptornegative human breast carcinoma cells. J Cell Physiol (1993) 155:556-67. doi:10.1002/jcp.1041550314

47. Martin JL, Baxter RC. Expression of insulin-like growth factor binding protein2 by MCF-7 breast cancer cells is regulated through the phosphatidylinositol 3-kinase/AKT/mammalian target of rapamycin pathway. Endocrinology (2007) 148:2532-41. doi:10.1210/en.2006-1335

48. Milewicz T, Gregoraszczuk EL, Sztefko K, Augustowska K, Krzysiek J, Rys J. Lack of synergy between estrogen and progesterone on local IGF-I, IGFBP-3 and IGFBP-2 secretion by both hormone-dependent and hormone-independent breast cancer explants in vitro. Effect of tamoxifen and mifepristone (RU 486). Growth Horm IGF Res (2005) 15:140-7. doi:10.1016/j.ghir.2004.12.006

49. Dubois V, Couissi D, Schonne E, Remacle C, Trouet A. Intracellular levels and secretion of insulin-like-growth-factor-binding proteins in MCF7/6, MCF-7/AZ and MDA-MB-231 breast cancer cells. Differential modulation by estrogens in serum-free medium. Eur J Biochem (1995) 232:47-53. doi:10.1111/j.1432-1033.1995.tb20779.x

50. Fog CK, Christensen IJ, Lykkesfeldt AE. Characterization of a human breast cancer cell line, MCF-7/RU58R-1, resistant to the pure antiestrogen RU 58,668. Breast Cancer Res Treat (2005) 91:133-44. doi:10.1007/s10549-004-5871-y

51. Korc-Grodzicki B, Ren N, Hilf R. Effects of estradiol on the expression and production of IGFBP-2 by R3230AC mammary tumor cells. Oncol Res (1996) 8:473-83.

52. Thomas LN, Wright AS, Lazier CB, Cohen P, Rittmaster RS. Prostatic involution in men taking finasteride is associated with elevated levels of insulin-like growth factor-binding proteins (IGFBPs)-2, -4, and -5. Prostate (2000) 42:203-10. doi:10.1002/(SICI)1097-0045(20000215)42:3<203::AID-PROS6> 3.0.CO;2-Y

53. Nickerson T, Pollak M. Bicalutamide (Casodex)-induced prostate regression involves increased expression of genes encoding insulin-like growth factor binding proteins. Urology (1999) 54:1120-5. doi:10.1016/S0090-4295(99) 00421-5

54. Le H, Arnold JT, McFann KK, Blackman MR. DHT and testosterone, but not DHEA or E2, differentially modulate IGF-I, IGFBP-2, and IGFBP-3 in human prostatic stromal cells. Am J Physiol Endocrinol Metab (2006) 290:E952-60. doi:10.1152/ajpendo.00451.2005

55. Martin JL, Pattison SL. Insulin-like growth factor binding protein-3 is regulated by dihydrotestosterone and stimulates deoxyribonucleic acid synthesis and cell proliferation in LNCaP prostate carcinoma cells. Endocrinology (2000) 141:2401-9. doi:10.1210/endo.141.7.7534

56. Arnold JT, Le H, McFann KK, Blackman MR. Comparative effects of DHEA vs. testosterone, dihydrotestosterone, and estradiol on proliferation and gene expression in human LNCaP prostate cancer cells. Am J Physiol Endocrinol Metab (2005) 288:E573-84. doi:10.1152/ajpendo.00454.2004

57. Degraff DJ, Aguiar AA, Chen Q, Adams LK, Williams BJ, Sikes RA. Androgen mediated translational and posttranslational regulation of IGFBP-2 in androgen-sensitive LNCaP human prostate cancer cells. Am J Transl Res (2010) 2:200-8.

58. Kiyama S, Morrison K, Zellweger T, Akbari M, Cox M, Yu D, et al. Castrationinduced increases in insulin-like growth factor-binding protein 2 promotes proliferation of androgen-independent human prostate LNCaP tumors. Cancer Res (2003) 63:3575-84.

59. Degraff DJ, Malik M, Chen Q, Miyako K, Rejto L, Aguiar AA, et al. Hormonal regulation of IGFBP-2 proteolysis is attenuated with progression to androgen insensitivity in the LNCaP progression model. J Cell Physiol (2007) 213:261-8. doi:10.1002/jcp. 21123

60. Stewart LV, Weigel NL. Role of insulin-like growth factor binding proteins in lalpha,25-dihydroxyvitamin $\mathrm{D}(3)$-induced growth inhibition of human prostate cancer cells. Prostate (2005) 64:9-19. doi:10.1002/pros.20212

61. Wang D, Nagpal ML, Lin T, Shimasaki S, Ling N. Insulin-like growth factorbinding protein-2: the effect of human chorionic gonadotropin on its gene regulation and protein secretion and its biological effects in rat Leydig cells. Mol Endocrinol (1994) 8:69-76. doi:10.1210/mend.8.1.7512196 
62. Hedbacker K, Birsoy K, Wysocki RW, Asilmaz E, Ahima RS, Farooqi IS, et al. Antidiabetic effects of IGFBP2, a leptin-regulated gene. Cell Metab (2010) 11:11-22. doi:10.1016/j.cmet.2009.11.007

63. Ooi GT, Orlowski CC, Brown AL, Becker RE, Unterman TG, Rechler MM. Different tissue distribution and hormonal regulation of messenger RNAs encoding rat insulin-like growth factor-binding proteins-1 and -2. Mol Endocrinol (1990) 4:321-8. doi:10.1210/mend-4-2-321

64. Straus DS, Takemoto CD. Effect of dietary protein deprivation on insulin-like growth factor (IGF)-I and -II, IGF binding protein-2, and serum albumin gene expression in rat. Endocrinology (1990) 127:1849-60. doi:10.1210/endo-1274- 1849

65. Tseng LY, Ooi GT, Brown AL, Straus DS, Rechler MM. Transcription of the insulin-like growth factor-binding protein-2 gene is increased in neonatal and fasted adult rat liver. Mol Endocrinol (1992) 6:1195-201. doi:10.1210/mend.6. 8.1383692

66. Boni-Schnetzler M, Binz K, Mary JL, Schmid C, Schwander J, Froesch ER. Regulation of hepatic expression of IGF I and fetal IGF binding protein mRNA in streptozotocin-diabetic rats. FEBS Lett (1989) 251:253-6. doi:10.1016/00145793(89)81465-6

67. Nagao K, Aman Yaman M, Murai A, Sasaki T, Saito N, Okumura J, et al. Insulin administration suppresses an increase in insulin-like growth factor binding protein-2 gene expression stimulated by fasting in the chicken. $\mathrm{Br}$ Poult Sci (2001) 42:501-4. doi:10.1080/00071660120070622

68. Schmid C, Schläpfer I, Waldvogel M, Meier PJ, Schwander J, Böni-Schnetzler $\mathrm{M}$, et al. Differential regulation of insulin-like growth factor binding protein (IGFBP)-2 mRNA in liver and bone cells by insulin and retinoic acid in vitro. FEBS Lett (1992) 303:205-9. doi:10.1016/0014-5793(92)80520-Q

69. Böni-Schnetzler M, Schmid C, Mary JL, Zimmerli B, Meier PJ, Zapf J, et al. Insulin regulates the expression of the insulin-like growth factor binding protein 2 mRNA in rat hepatocytes. Mol Endocrinol (1990) 4:1320-6. doi:10.1210/mend-4-9-1320

70. Crespi EJ, Steckler TL, Mohankumar PS, Padmanabhan V. Prenatal exposure to excess testosterone modifies the developmental trajectory of the insulin-like growth factor system in female sheep. J Physiol (2006) 572: 119-30.

71. Reijnders CM, Bravenboer N, Holzmann PJ, Bhoelan F, Blankenstein MA, Lips P. In vivo mechanical loading modulates insulin-like growth factor binding protein-2 gene expression in rat osteocytes. Calcif Tissue Int (2007) 80:137-43. doi:10.1007/s00223-006-0077-4

72. Boisclair YR, Yang YW, Stewart JM, Rechler MM. Insulin-like growth factorI and insulin stimulate the synthesis of IGF-binding protein-2 in a human embryonic kidney cell line. Growth Regul (1994) 4:136-46.

73. Cazals V, Nabeyrat E, Corroyer S, de Keyzer Y, Clement A. Role for NF-kappa B in mediating the effects of hyperoxia on IGF-binding protein 2 promoter activity in lung alveolar epithelial cells. Biochim Biophys Acta (1999) 1448:349-62. doi:10.1016/S0167-4889(98)00095-0

74. Cazals V, Mouhieddine B, Maitre B, Le Bouc Y, Chadelat K, Brody JS, et al. Insulin-like growth factors, their binding proteins, and transforming growth factor-beta 1 in oxidant-arrested lung alveolar epithelial cells. J Biol Chem (1994) 269:14111-7.

75. Chetty A, Manzo N, Waxman AB, Nielsen HC. Modulation of IGF-binding protein-2 and -3 in hyperoxic injury in developing rat lung. Pediatr Res (2005) 58:222-8. doi:10.1203/01.PDR.0000169973.42653.68

76. Liu HC, Chang LW, Rong ZH, Zhu HP, Zhang QS, Chen HB, et al. [Relation of insulin-like growth factor binding protein-2 with hyperoxia-induced lung injury in term and premature neonatal rats]. Zhongguo Wei Zhong Bing Ji Jiu Yi Xue (2008) 20:331-4. doi:10.3736/jcim20080401

77. Yazawa T, Sato H, Shimoyamada H, Okudela K, Woo T, Tajiri M, et al. Neuroendocrine cancer-specific up-regulating mechanism of insulin-like growth factor binding protein-2 in small cell lung cancer. Am J Pathol (2009) 175:976-87. doi:10.2353/ajpath.2009.081004

78. Bostedt KT, Schmid C, Ghirlanda-Keller C, Olie R, Winterhalter KH, Zapf J. Insulin-like growth factor (IGF) I down-regulates type 1 IGF receptor (IGF $1 \mathrm{R})$ and reduces the IGF I response in A549 non-small-cell lung cancer and Saos-2/B-10 osteoblastic osteosarcoma cells. Exp Cell Res (2001) 271:368-77. doi:10.1006/excr.2001.5388

79. Yakar S, Domene H, Meidan R, Cassorla F, Gilad I, Koch I, et al. Growth hormone $(\mathrm{GH})$ stimulates insulin-like growth factor-I (IGF-I) and IGF-binding protein (IGFBP)-2 gene expression in spleens of juvenile rats. Horm Metab Res (1994) 26:363-6. doi:10.1055/s-2007-1001707

80. Oh YS, Kim EJ, Schaffer BS, Kang YH, Binderup L, MacDonald RG, et al. Synthetic low-calcaemic vitamin $\mathrm{D}(3)$ analogues inhibit secretion of insulin-like growth factor II and stimulate production of insulin-like growth factor-binding protein-6 in conjunction with growth suppression of HT-29 colon cancer cells. Mol Cell Endocrinol (2001) 183:141-9. doi:10.1016/S0303-7207(01)00598-6

81. Averbukh E, Weiss O, Halpert M, Yanko R, Moshe R, Nephesh I, et al. Gene expression of insulin-like growth factor-I, its receptor and binding proteins in retina under hypoxic conditions. Metabolism (1998) 47:1331-6. doi:10.1016/S0026-0495(98)90300-6

82. Nachtrab G, Czerwinski M, Poss KD. Sexually dimorphic fin regeneration in zebrafish controlled by androgen/GSK3 signaling. Curr Biol (2011) 21:1912-7. doi:10.1016/j.cub.2011.09.050

83. Ernst CW, White ME. Hormonal regulation of IGF-binding protein-2 expression in proliferating C2C12 myoblasts. J Endocrinol (1996) 149:417-29. doi:10.1677/joe.0.1490417

84. Diesing D, Elmlinger MW, Schuett BS, Weidemann W, Romalo G, Schweikert $\mathrm{HU}$, et al. Genital skin fibroblasts (GF) of patients with androgen insensitivity syndrome express higher insulin-like growth factor binding protein (IGFBP)2, -3 and -5 than GF of normally virilized males. Horm Res (2003) 60:73-8. doi:10.1159/000071874

85. Kutoh E, Margot JB, Schwander J. Genomic structure and regulation of the promoter of the rat insulin-like growth factor binding protein-2 gene. $\mathrm{Mol}$ Endocrinol (1993) 7:1205-16. doi:10.1210/mend.7.9.7504179

86. Brown AL, Rechler MM. Cloning of the rat insulin-like growth factor-binding protein-2 gene and identification of a functional promoter lacking a TATA box. Mol Endocrinol (1990) 4:2039-51. doi:10.1210/mend-4-12-2039

87. Boisclair YR, Brown AL, Casola S, Rechler MM. Three clustered Spl sites are required for efficient transcription of the TATA-less promoter of the gene for insulin-like growth factor-binding protein-2 from the rat. J Biol Chem (1993) 268:24892-901.

88. Song S, Lee CY, Green ML, Chung CS, Simmen RC, Simmen FA. The unique endometrial expression and genomic organization of the porcine IGFBP-2 gene. Mol Cell Endocrinol (1996) 120:193-202. doi:10.1016/0303-7207(96) 03837-3

89. Kwak I, Song S, Blum JL, Simmen RC, Simmen FA. Enhancer- and silencerlike sequences that mediate insulin-like growth factor-binding protein-2 gene expression in uterine cells of pregnancy. DNA Cell Biol (2006) 25:6-18. doi:10.1089/dna.2006.25.6

90. Badinga L, Song S, Simmen RC, Simmen FA. A distal regulatory region of the insulin-like growth factor binding protein-2 (IGFBP-2) gene interacts with the basic helix-loop-helix transcription factor, AP-4. Endocrine (1998) 8:281-9. doi:10.1385/ENDO:8:3:281

91. Cindolo L, Franco R, Cantile M, Schiavo G, Liguori G, Chiodini P, et al. NeuroD1 expression in human prostate cancer: can it contribute to neuroendocrine differentiation comprehension? Eur Urol (2007) 52:1365-73. doi:10.1016/j.eururo.2006.11.030

92. Hilleson-Gayne CK, Clapper JA. Effects of decreased estradiol-17beta on the serum and anterior pituitary IGF-I system in pigs. J Endocrinol (2005) 187:369-78. doi:10.1677/joe.1.06253

93. Ribeiro MF, Garcia-Segura LM. Dehydroepiandrosterone regulates insulin-like growth factor-1 system in adult rat hypothalamus. Endocrine (2002) 17:129-34. doi:10.1385/ENDO:17:2:129

94. Fuller GN, Rhee CH, Hess KR, Caskey LS, Wang R, Bruner JM, et al. Reactivation of insulin-like growth factor binding protein 2 expression in glioblastoma multiforme: a revelation by parallel gene expression profiling. Cancer Res (1999) 59:4228-32.

95. Mehrian-Shai R, Chen CD, Shi T, Horvath S, Nelson SF, Reichardt JK, et al. Insulin growth factor-binding protein 2 is a candidate biomarker for PTEN status and PI3K/Akt pathway activation in glioblastoma and prostate cancer. Proc Natl Acad Sci U S A (2007) 104:5563-8. doi:10.1073/pnas.0609139104

96. Ahani N, Karimi AM, Shirkoohi R, Rokouei M, Alipour EM, Nikravesh A. Expression of insulin-like growth factor binding protein-2 (IGFBP-2) gene in negative and positive human cytomegalovirus glioblastoma multiforme tissues. Med Oncol (2014) 31:812. doi:10.1007/s12032-013-0812-4

97. Fukushima T, Tezuka T, Shimomura T, Nakano S, Kataoka H. Silencing of insulin-like growth factor-binding protein-2 in human glioblastoma cells 
reduces both invasiveness and expression of progression-associated gene CD24. J Biol Chem (2007) 282:18634-44. doi:10.1074/jbc.M609567200

98. Moore LM, Holmes KM, Smith SM, Wu Y, Tchougounova E, Uhrbom L, et al. IGFBP2 is a candidate biomarker for Ink4a-Arf status and a therapeutic target for high-grade gliomas. Proc Natl Acad Sci U S A (2009) 106:16675-9. doi:10.1073/pnas.0900807106

99. Altiok N, Ersoz M, Koyuturk M. Estradiol induces JNK-dependent apoptosis in glioblastoma cells. Oncol Lett (2011) 2:1281-5.

100. DeMambro VE, Maile L, Wai C, Kawai M, Cascella T, Rosen CJ, et al. Insulinlike growth factor-binding protein-2 is required for osteoclast differentiation. J Bone Miner Res (2012) 27:390-400. doi:10.1002/jbmr.545

101. Heald A, Kaushal K, Anderson S, Redpath M, Durrington PN, Selby PL, et al. Effects of hormone replacement therapy on insulin-like growth factor (IGF)-I, IGF-II and IGF binding protein (IGFBP)-1 to IGFBP-4: implications for cardiovascular risk. Gynecol Endocrinol (2005) 20:176-82. doi:10.1080/ 09513590400027406

102. Rooman RP, De Beeck LO, Martin M, van Doorn J, Mohan S, Du Caju MV. Ethinylestradiol and testosterone have divergent effects on circulating IGF system components in adolescents with constitutional tall stature. Eur J Endocrinol (2005) 152:597-604. doi:10.1530/eje.1.01880

103. Münzer T, Rosen CJ, Harman SM, Pabst KM, St Clair C, Sorkin JD, et al. Effects of GH and/or sex steroids on circulating IGF-I and IGFBPs in healthy, aged women and men. Am J Physiol Endocrinol Metab (2006) 290:E1006-13. doi:10.1152/ajpendo.00166.2005

104. Howard HJ, Ford JJ. Relationships among concentrations of steroids, inhibin, insulin-like growth factor-1 (IGF-1), and IGF-binding proteins during follicular development in weaned sows. Biol Reprod (1992) 47:193-201. doi:10.1095/ biolreprod47.2.193

105. Walters KA, Armstrong DG, Telfer EE. Bovine mural granulosa cells, and not the oocyte, are the major source of proteases capable of IGFBP-2 degradation. Anim Reprod Sci (2007) 98:365-70. doi:10.1016/j.anireprosci.2006.04.047

106. Simmen FA, Simmen RC, Geisert RD, Martinat-Botte F, Bazer FW, Terqui M. Differential expression, during the estrous cycle and pre- and postimplantation conceptus development, of messenger ribonucleic acids encoding components of the pig uterine insulin-like growth factor system. Endocrinology (1992) 130:1547-56. doi:10.1210/en.130.3.1547

107. Geisert RD, Chamberlain CS, Vonnahme KA, Malayer JR, Spicer LJ. Possible role of kallikrein in proteolysis of insulin-like growth factor binding proteins during the oestrous cycle and early pregnancy in pigs. Reproduction (2001) 121:719-28. doi:10.1530/rep.0.1210719

108. Elmlinger MW, Grund R, Buck M, Wollmann HA, Feist N, Weber MM, et al. Limited proteolysis of the IGF binding protein-2 (IGFBP-2) by a specific serine protease activity in early breast milk. Pediatr Res (1999) 46:76-81. doi:10.1203/00006450-199907000-00013

109. Lee CY, Bazer FW, Simmen FA. Expression of components of the insulin-like growth factor system in pig mammary glands and serum during pregnancy and pseudopregnancy: effects of oestrogen. J Endocrinol (1993) 137:473-83. doi:10.1677/joe.0.1370473

110. Maxwell P, van den Berg HW. Changes in the secretion of insulin-like growth factor binding proteins -2 and -4 associated with the development of tamoxifen resistance and estrogen independence in human breast cancer cell lines. Cancer Lett (1999) 139:121-7. doi:10.1016/S0304-3835(99)00009-9

111. Juncker-Jensen A, Lykkesfeldt AE, Worm J, Ralfkiaer U, Espelund U, Jepsen JS. Insulin-like growth factor binding protein 2 is a marker for antiestrogen resistant human breast cancer cell lines but is not a major growth regulator. Growth Horm IGF Res (2006) 16:224-39. doi:10.1016/j.ghir.2006.06.005

112. Yee D, Lee AV. Crosstalk between the insulin-like growth factors and estrogens in breast cancer. J Mammary Gland Biol Neoplasia (2000) 5:107-15. doi:10.1023/A:1009575518338

113. Eder IE, Haag P, Basik M, Mousses S, Bektic J, Bartsch G, et al. Gene expression changes following androgen receptor elimination in LNCaP prostate cancer cells. Mol Carcinog (2003) 37:181-91. doi:10.1002/mc.10136

114. Nickerson T, Pollak M, Huynh H. Castration-induced apoptosis in the rat ventral prostate is associated with increased expression of genes encoding insulin-like growth factor binding proteins 2,3,4 and 5. Endocrinology (1998) 139:807-10. doi:10.1210/endo.139.2.5912

115. Zapf J, Schmid C, Guler HP, Waldvogel M, Hauri C, Futo E, et al. Regulation of binding proteins for insulin-like growth factors (IGF) in humans. Increased expression of IGF binding protein 2 during IGF I treatment of healthy adults and in patients with extrapancreatic tumor hypoglycemia. J Clin Invest (1990) 86:952-61. doi:10.1172/JCI114797

116. Blum WF, Horn N, Kratzsch J, Jørgensen JO, Juul A, Teale D, et al. Clinical studies of IGFBP-2 by radioimmunoassay. Growth Regul (1993) 3:100-4.

117. Bannink EM, van Doorn J, Stijnen T, Drop SL, de Muinck Keizer-Schrama SM. Free dissociable insulin-like growth factor I (IGF-I), total IGF-I and their binding proteins in girls with Turner syndrome during long-term growth hormone treatment. Clin Endocrinol (Oxf) (2006) 65:310-9. doi:10.1111/j.1365-2265. 2006.02594.x

118. Katz LE, Liu F, Baker B, Agus MS, Nunn SE, Hintz RL, et al. The effect of growth hormone treatment on the insulin-like growth factor axis in a child with nonislet cell tumor hypoglycemia. J Clin Endocrinol Metab (1996) 81:1141-6. doi:10.1210/jcem.81.3.8772589

119. Kassem M, Brixen K, Mosekilde L, Blum WF, Flyvbjerg A. Effects of growth hormone treatment on serum levels of insulin-like growth factors (IGFs) and IGF binding proteins 1-4 in postmenopausal women. Clin Endocrinol (Oxf) (1998) 49:747-56. doi:10.1046/j.1365-2265.1998.00606.x

120. Coschigano KT, Holland AN, Riders ME, List EO, Flyvbjerg A, Kopchick JJ. Deletion, but not antagonism, of the mouse growth hormone receptor results in severely decreased body weights, insulin, and insulin-like growth factor I levels and increased life span. Endocrinology (2003) 144:3799-810. doi:10.1210/en.2003-0374

121. Young SC, Underwood LE, Celniker A, Clemmons DR. Effects of recombinant insulin-like growth factor-I (IGF-I) and growth hormone on serum IGFbinding proteins in calorically restricted adults. J Clin Endocrinol Metab (1992) 75:603-8. doi:10.1210/jc.75.2.603

122. Lee PD, Durham SK, Martinez V, Vasconez O, Powell DR, Guevara-Aguirre J. Kinetics of insulin-like growth factor (IGF) and IGF-binding protein responses to a single dose of growth hormone. JClin Endocrinol Metab (1997) 82:2266-74. doi:10.1210/jcem.82.7.4048

123. Kicman AT, Miell JP, Teale JD, Powrie J, Wood PJ, Laidler P, et al. Serum IGF-I and IGF binding proteins 2 and 3 as potential markers of doping with human GH. Clin Endocrinol (Oxf) (1997) 47:43-50. doi:10.1046/j.1365-2265.1997. 2111036.x

124. Guha N, Erotokritou-Mulligan I, Nevitt SP, Francis M, Bartlett C, Cowan DA, et al. Biochemical markers of recombinant human insulin-like growth factor-I (rhIGF-I)/rhIGF binding protein-3 (rhIGFBP-3) misuse in athletes. Drug Test Anal (2013) 5(11-12):843-9. doi:10.1002/dta.1562

125. Donahue LR, Watson G, Beamer WG. Regulation of metabolic water and protein compartments by insulin-like growth factor-I and testosterone in growth hormone-deficient lit/lit mice. J Endocrinol (1993) 139:431-9. doi:10.1677/joe. 0.1390431

126. McCann JP, Loo SC, Aalseth DL, Abribat T. Differential effects of GH stimulation on fasting and prandial metabolism and plasma IGFs and IGFbinding proteins in lean and obese sheep. J Endocrinol (1997) 154:329-46. doi:10.1677/joe.0.1540329

127. Thrailkill K, Quattrin T, Baker L, Litton J, Dwigun K, Rearson M, et al. Dual hormonal replacement therapy with insulin and recombinant human insulinlike growth factor (IGF)-I in insulin-dependent diabetes mellitus: effects on the growth hormone/IGF/IGF-binding protein system. JClin Endocrinol Metab (1997) 82:1181-7. doi:10.1210/jc.82.4.1181

128. Wolf E, Jehle PM, Weber MM, Sauerwein H, Daxenberger A, Breier BH, et al. Human insulin-like growth factor I (IGF-I) produced in the mammary glands of transgenic rabbits: yield, receptor binding, mitogenic activity, and effects on IGF-binding proteins. Endocrinology (1997) 138:307-13. doi:10.1210/en.138.1.307

129. Metzger F, Sajid W, Saenger S, Staudenmaier C, van der Poel C, Sobottka $\mathrm{B}$, et al. Separation of fast from slow anabolism by site-specific PEGylation of insulin-like growth factor I (IGF-I). J Biol Chem (2011) 286:19501-10. doi:10.1074/jbc.M110.172189

130. Wolf E, Kramer R, Blum WF, Foll J, Brem G. Consequences of postnatally elevated insulin-like growth factor-II in transgenic mice: endocrine changes and effects on body and organ growth. Endocrinology (1994) 135:1877-86. doi:10.1210/en.135.5.1877

131. Rogler CE, Yang D, Rossetti L, Donohoe J, Alt E, Chang CJ, et al. Altered body composition and increased frequency of diverse malignancies in insulin-like growth factor-II transgenic mice. J Biol Chem (1994) 269:13779-84. 
132. Reijnders CM, Koster JG, van Buul-Offers SC. Overexpression of human IGFII mRNA in the brain of transgenic mice modulates IGFBP-2 gene expression in the medulla oblongata. J Endocrinol (2004) 182:445-55. doi:10.1677/joe.0. 1820445

133. Grinspoon S, Miller K, Herzog D, Clemmons D, Klibanski A. Effects of recombinant human insulin-like growth factor (IGF)-I and estrogen administration on IGF-I, IGF binding protein (IGFBP)-2, and IGFBP-3 in anorexia nervosa: a randomized-controlled study. J Clin Endocrinol Metab (2003) 88:1142-9. doi:10.1210/jc.2002-021402

134. Wheatcroft SB, Kearney MT, Shah AM, Ezzat VA, Miell JR, Modo M, et al. IGF-binding protein-2 protects against the development of obesity and insulin resistance. Diabetes (2007) 56:285-94. doi:10.2337/db06-0436

135. Wheatcroft SB, Kearney MT. IGF-dependent and IGF-independent actions of IGF-binding protein-1 and -2: implications for metabolic homeostasis. Trends Endocrinol Metab (2009) 20:153-62. doi:10.1016/j.tem.2009.01.002

136. Vrieling A, Voskuil DW, Bueno de Mesquita HB, Kaaks R, van Noord PA, Keinan-Boker L, et al. Dietary determinants of circulating insulin-like growth factor (IGF)-I and IGF binding proteins $1,-2$ and -3 in women in the Netherlands. Cancer Causes Control (2004) 15:787-96. doi:10.1023/B:CACO. 0000043429.51915.c6

137. Crowe FL, Key TJ, Allen NE, Appleby PN, Roddam A, Overvad K, et al. The association between diet and serum concentrations of IGF-I, IGFBP1, IGFBP-2, and IGFBP-3 in the European prospective investigation into cancer and nutrition. Cancer Epidemiol Biomarkers Prev (2009) 18:1333-40. doi:10.1158/1055-9965.EPI-08-0781

138. Pucilowska JB, Davenport ML, Kabir I, Clemmons DR, Thissen JP, Butler $\mathrm{T}$, et al. The effect of dietary protein supplementation on insulin-like growth factors (IGFs) and IGF-binding proteins in children with shigellosis. J Clin Endocrinol Metab (1993) 77:1516-21. doi:10.1210/jc. 77.6.1516

139. Vrieling A, Voskuil DW, Bonfrer JM, Korse CM, van Doorn J, Cats A, et al. Lycopene supplementation elevates circulating insulin-like growth factor binding protein-1 and -2 concentrations in persons at greater risk of colorectal cancer. Am J Clin Nutr (2007) 86:1456-62.

140. Arafat AM, Weickert MO, Frystyk J, Spranger J, Schöfl C, Möhlig M, et al. The role of insulin-like growth factor (IGF) binding protein-2 in the insulinmediated decrease in IGF-I bioactivity. J Clin Endocrinol Metab (2009) 94:5093-101. doi:10.1210/jc.2009-0875

141. McGuire MA, Dwyer DA, Harrell RJ, Bauman DE. Insulin regulates circulating insulin-like growth factors and some of their binding proteins in lactating cows. Am J Physiol (1995) 269:E723-30.
142. Butler ST, Pelton SH, Butler WR. Insulin increases 17 beta-estradiol production by the dominant follicle of the first postpartum follicle wave in dairy cows. Reproduction (2004) 127:537-45. doi:10.1530/rep.1.00079

143. Counts DR, Gwirtsman H, Carlsson LM, Lesem M, Cutler GB Jr. The effect of anorexia nervosa and refeeding on growth hormone-binding protein, the insulin-like growth factors (IGFs), and the IGF-binding proteins. J Clin Endocrinol Metab (1992) 75:762-7. doi:10.1210/jcem.75.3.1381372

144. Morishita D, Sasaki K, Wakita M, Hoshino S. Effect of fasting on serum insulinlike growth factor-I (IGF-I) levels and IGF-I-binding activity in cockerels. J Endocrinol (1993) 139:363-70. doi:10.1677/joe.0.1390363

145. Straus DS. Nutritional regulation of hormones and growth factors that control mammalian growth. FASEB J (1994) 8:6-12.

146. Maxwell A, Butterwick R, Yateman M, Batt RM, Cotterill A, Camacho-Hubner C. Nutritional modulation of canine insulin-like growth factors and their binding proteins. J Endocrinol (1998) 158:77-85. doi:10.1677/joe.0.1580077

147. Peterson BC, Waldbieser GC. Effects of fasting on IGF-I, IGF-II, and IGF-binding protein mRNA concentrations in channel catfish (Ictalurus punctatus). Domest Anim Endocrinol (2009) 37:74-83. doi:10.1016/j.domaniend. 2009.03.004

148. Munoz-Gutierrez M, Blache D, Martin GB, Scaramuzzi RJ. Ovarian follicular expression of mRNA encoding the type I IGF receptor and IGFbinding protein-2 in sheep following five days of nutritional supplementation with glucose, glucosamine or lupins. Reproduction (2004) 128:747-56. doi:10.1530/rep.1.00439

Conflict of Interest Statement: Dr. Elisa Wirthgen is part of the Ligandis GbR team. This relation has no effect on the content of the manuscript. The other co-authors report no conflicts of interest.

Received: 04 February 2014; accepted: 20 March 2014; published online: 07 April 2014. Citation: Hoeflich A, Wirthgen E, David R, Classen CF, Spitschak M and Brenmoehl J (2014) Control of IGFBP-2 expression by steroids and peptide hormones in vertebrates. Front. Endocrinol. 5:43. doi: 10.3389/fendo.2014.00043

This article was submitted to Cancer Endocrinology, a section of the journal Frontiers in Endocrinology.

Copyright (c) 2014 Hoeflich, Wirthgen, David, Classen, Spitschak and Brenmoehl. This is an open-access article distributed under the terms of the Creative Commons Attribution License (CC BY). The use, distribution or reproduction in other forums is permitted, provided the original author(s) or licensor are credited and that the original publication in this journal is cited, in accordance with accepted academic practice. No use, distribution or reproduction is permitted which does not comply with these terms. 